not lead alkyls should be banned from petroleum. Ironically, it may be the manufacturers themselves who are forced to conclude that they can no longer afford to have their cars run on leaded petroleum, whatever recommendations the EPA comes up with in December. The automobile manufacturers must by 1975 meet strict regulations on the amount of unburnt gases and nitrogen oxides emitted from automobile exhausts, and one method which at present looks promising is to attach a catalyst to the exhaust system to reduce nitric oxide and to oxidize carbon monoxide. Lead, however, poisons the catalysts.

Apart from its findings on the levels of lead in the blood of city dwellers, the panel also pinpointed areas where more research is needed. For one thing, the panel points out that monitoring of both city air and food is totally inadequate to determine either the source of lead which eventually finds its way into human blood, or to provide warnings of potential risk. But the chief areas where more extensive research is called for lie in the biological sciences themselves. For example, the panel says that studies are required to determine whether the body burden of lead increases with age, and the assumption that the non-diffusable fraction is tightly bound in bone, and therefore biologically. inert, also requires further detailed examination.

A more important recommendation, and one which throws into relief the panel's tacit assumption that blood lead levels below $40 \mathrm{~g}$ are safe, is the suggestion that studies on the biological effects of low levels of exposure to lead are urgently required. "The subtle effects on behaviour of low lead exposure of long duration without prior exposure may be manifest in two types of disorders: the dulling of mentation and chronic hyperkinesis", the panel points out. "No information is available regarding the possibility of cause and effect in what may be an extremely important problem."

\section{TECHNOLOGY ASSESSMENT Daddario's Kite Flies Yet}

by our Washington Correspondent

THE Office of Technology Assessment, like an old soldier, refuses to die. A proposal to set up within the legislative branch of the Federal Government an agency designed to assess the likely consequences of technological projects has been kicking around in the House of Representatives Subcommittee on Research and Development for the past four years, and its ancestry can be traced back a good deal further than that. But, just as the idea seemed finally to have been laid to rest, it has appeared again with enough vigour and support to take it through the rest of the congressional mill and probably even into the statue books. A bill to set up the office was introduced into the House by $\mathrm{Mr}$ John Davis, chairman of the Subcommittee on Research and Development and the rest of his committee members a few days before members of Congress dispersed for their Summer vacations. It was referred to Mr Davis' committee, and has since been sent back to Congress without amendment and with a report explaining why it would be "shortsighted in the extreme, if not disastrous" for Congress to turn the idea down.

The bill, which is in most respects identical with a bill introduced by Emilio Q. Daddario, Mr Davis's predecessor as chairman of the research and development subcommittee, would establish an Office of Technology Assessment charged with appraising the impacts of the applications of technology and with helping Congress to determine the relative priorities of the projects before it.

The chief reason for the bill, and without doubt its strongest asset on Capitol Hill, is that the Administration at present has all the resources at its disposal for making decisions on technological matters and Congress is illequipped to challenge them. To help redress the balance, the proposed Office of Technology Assessment (OTA) will provide information to congressional committees and serve as an early warning system for likely undesirable social effects of legislation involving technology. All these functions would be performed at a cost of $\$ 5$ million for the office's first year of operation.

Jobs specifically earmarked for the OTA in the bill are to identify existing or probable impacts of technology, where possible to establish cause and effect relationships between technological advances and social or financial consequences, to determine alternative programmes to achieve specific goals, to identify areas where more research is needed to support the assessment, and to furnish the results of these labours to the appropriate legislative body. The OTA will have the Library of Congress to help carry out its tasks, and the National Science Foundation to cooperate on the development of techniques of technology assessment, and to award grants and contracts for research needed by the OTA.

A panel consisting of eleven members would be responsible for the policy of the OTA and an operational unit, headed by a director, would be charged with the task of carrying it out. Two Senators, two members of the House of Representatives, the Comptroller General, the director of the Congres- sional Research Service of the Library of Congress, the director of the OTA itself, and "four especially qualified members from the general public" appointed by the President with the Senate's approval would together provide the personnel for the Technology Assessment Board. The director would be appointed for a six-year term and the public members of the board would serve for four years each, with the possibility of being reappointed once. Assessments could be instigated by the board or the director, but the chief users of the office's expertise are expected to be congressional committees whose chairmen could ask for specific studies to be carried out. Like the FBI, the OTA would be expected to furnish a report without coming to any conclusions.

Although the way in which the OTA will in theory carry out its business, and the rationale that underpins the attempt to set it up, is clear, thirteen days of hearings and four years of rumination by the Subcommittee on Research and Development have failed to provide a convincing description of how it will work in practice. For one thing, if the OTA is to be used to check on a particular action of the Executive, it will have to move with sufficient speed to produce a report that is not a post mortem, and for another, independent members of the public who are both equipped and willing to serve on such a body are rare indeed. The new bill has at least alleviated the problem of finding staff for the Technology Assessment Board to the extent that it has cut the number of public members down from seven in the original proposal to six and finally to four in Mr Davis's new bill.

If the bill survives intact the congressional mill-as indeed it stands every chance of doing, for Congress is not noted for turning down measures that are designed to strengthen its hand against the Executive-the Office of Technology Assessment would be essentially Mr Daddario's baby, for it was he who introduced the legislation leading up to the new bill, and it was under his chairmanship that the subcommittee conducted its hearings. Although the need for Congress to be kept informed of the likely consequences of new technology was agreed by all the witnesses before the committee, few aspects of the proposal remained uncriticized. Dr William D. McElroy, Director of the National Science Foundation, for example, told the subcommittee that the office would lack credibility and that it may better serve to coordinate the work of agencies that are already engaged in technology assessment. Those are criticisms that the new legislation has clearly failed to answer. 